\title{
Anthropology of Tourism: Researching Interactions between Hosts and Guests
}

\author{
Barbora Půtová \\ e-mail: barbora.putova@ff.cuni.cz \\ Institute of Ethnology, Faculty of Arts, Charles University, Prague, Czech Republic
}

Půtová, B. (2018). Anthropology of Tourism: Researching Interactions between Hosts and Guests. Czech Journal of Tourism, 7(1), 71-92. DOI: 10.1515/cjot-2018-0004.

\begin{abstract}
This study focuses on the theoretical analysis of social interaction and relationship between guests and hosts from the perspective of anthropology of tourism. In the 1960s and 1970s, attention was paid predominantly to anthropological reflection of negative socio-cultural impacts of tourism on host communities. However, towards the end of the 1980s and during the 1990s the research focus began to shift towards an analysis and interpretation of the influence of commodification on the perceptions of identity and authenticity of the host culture, while the positive aspects of tourism began to be recognized as well. This study aims to present an overview of the basic approaches within the anthropology of tourism to social interaction between guests and hosts. The objective of the study is to provide a summary of miscellaneous approaches to and views on this issue.
\end{abstract}

\section{Keywords}

tourism, anthropology, interaction, hosts, guests, social interaction, impact

JEL classification: O10, Z10, Z39 


\section{Introduction}

Interactions between hosts and guests became the central topic of anthropology of tourism in the 1970s (MacCannell, 1976; Smith, 1977, 1989). The focus was predominantly on the negative socio-cultural impacts of tourism on host communities and related processes of socio-cultural change. Hence, binary characteristics and the opposition between the guest and the host were established (Nash, 1981; Sherlock, 2001; Picken, 2006; Chambers, 2007). Guests were simply the tourists, while hosts were the members of the local community and its residents. However, "the main problem with the approach adopted in tourism studies has been to assume that the host is a local resident of the destination" (Andrews, 2000, p. 237). The local community consists of residents living in the destination visited by tourists although this community may not enter in direct contact with them (Turner \& Reisinger, 2011; Griffiths \& Sharpley, 2012; Sharpley, 2014). Residents may only work in the destination without actually living there, or they can live and work there, while they might not come from the destination. The local community includes tourist personnel as well as tourism business owners, entertainers and service providers. The category of guests includes, besides tourists, also mediators, investors, tourism workers, service sellers and providers, experts and sales professionals, migrating workers and expats, workers in press and media (Canziani \& Francioni, 2013).

Interactions between hosts and guests include relations between members of different cultures, which is why "the greater the ethnic and cultural distance between the host and tourist personnel, the greater the confusion and misunderstanding the two groups are likely to encounter, and the less natural they are likely to act" (Smith, 1989, p. 271). The nature of these interactions differs depending on factors that include, besides cultural distance between tourists and hosts, the length of tourists' stay or season, their attitudes and expectations, their type and numbers (Smith, 1977; Shaw \& Williams, 2004). Hosts are traditionally considered territorial and static, whereas tourists are considered mobile. The polarities of distance and nearness, movement and temporariness or immobility and invariability expressing guests and hosts destroy the virtual and globalized world. That is the reason why fixed categories of space and identities turn into "fluid, contested social roles that people move into, out of, and between as they negotiate extensive overlapping mobilities and social memberships" (Molz \& Gibson, 2007, p. 7). Considering the extent of the hosts' interaction with guests, their position or power, these hosts cannot be unambiguously identified as such as the category of the 'host' is "ultimately too simple a term in a complex world" (Selwyn, 1996, p. 8). Furthermore, the share of local residents interacting with tourists and their ability to promote their thoughts and interests reveals one of tourist myths, according to which "in successful tourist destinations, the natives are always friendly" (Selwyn, 1996, p. 21). It follows that hosts cannot be considered a homogeneous group as they are characterized by different and changeable attitudes, values or requirements (Murphy, 1985).

The socio-cultural impacts (Table 1) and consequences of tourism on hosts relate to transformation of value systems and standards, social structures and relationships, institutions and traditional lifestyles. Guests necessarily influence anything from the nature 
of interpersonal relationships and social organizations, social stratification of the society, division of labour, separation of powers, rhythm of social life to habits and art. These changes influence wider cultural, social, political, economic, and ecological processes that are typical of guests and hosts. Socio-cultural impacts of tourism on the host culture are often classified both as positive since they may result in revitalization of tradition and transmission of cultural knowledge, and as negative, pertaining, for instance, to the commodification of local culture or to tourists' deviant behavior. Moreover, in addition to the ecological change that transforms the original environment of a destination, we should not omit other positive impacts (income, employment or infrastructure development) and negative impacts (an increase in prices of goods and services in tourist destinations or the shift away from traditional economic activities). Descriptions, interpretations and assessments of the consequences of socio-cultural impacts need to be analyzed in multiple ways, since "the question of what sort of social relationships grow up in tourism encounters can only be answered by detailed and descriptive studies" (Crick, 1989, p. 330).

Table 1 Cross-cultural tourist-host contact

\begin{tabular}{ll}
\hline Positive Effects & Negative Effects \\
\hline Developing positive attitudes about each other & Developing negative attitudes about each other \\
Learning about each other's culture and & $\begin{array}{l}\text { Tension, hostility, suspicion and } \\
\text { customs }\end{array}$ \\
Redunderstanding \\
Developing friendships & Isolation, segregation, and separation \\
Developing pride, appreciation, understanding, & Clashes of values \\
respect and tolerance for each other's culture & Feelings of inferiority and superiority \\
Increasing self-esteem & Communication problems \\
& Ethnocentrism \\
Psychological satisfaction with interaction & Culture shock \\
& Dissatisfaction with mutual interaction
\end{tabular}

Source: Robinson (1999)

\section{Methodology}

Within the context of the text above, the goal of this paper is to present authors' complex overview of the approaches to the issue of interaction between hosts and guests related to the development of anthropology of tourism. So far, most authors have only focused on a certain theoretical model. Therefore, they have not fully and comprehensively revealed the stages of development and changes in the 'host-guest' relationship in anthropology of tourism, but they aspire to describe the gradual shift from negative impacts of tourism on the host community to positive ones. Tourism becomes an 
important element through which local communities can control and regulate the degree of power they have over a dominant group of guests. At the same time, tourism reinforces hosts' cultural identity, stimulates their interest in the local culture, cultural heritage, and ethnic identity. Therefore, the main research question of this paper concerns the development of interactions between hosts and guests and tourism impacts. This descriptive case study strives to process and describe interactions between hosts and guests while summarizing the general framework for studying the host-guest encounters and impacts of tourism. In tourism anthropology, the socio-cultural impacts of tourism are necessary for monitoring and predicting changes in societal value systems, community structures, social relationships, individual behaviour, ways and standards of living and traditions.

\section{The hospitality phenomenon: hosts' and guests' status and role}

In anthropology of tourism, hospitality refers to 'geography of proximity' (Derrida \& Dufourmantelle, 2000, p. 2) and it is viewed in the context of the host-guest relationship. However, modern tourism disrupted pre-modern host-guest relationships based on agreements of protection, reciprocity and reciprocal rights and duties. Before, hosts secured guests' satisfaction and guests became temporary members of the family while adhering to the rules of the host's home. Reciprocity and mutuality formed "an inevitable part of the social exchange in the host-guest relationship" (Tucker, 2003, p. 80). Traditional host-guest relationships resulted in commercialization and commodification. Therefore, tourists and travellers are no longer merely guests; tourists turned into consumers of experiences and hosts became providers of these experiences (Cohen, 1974; Leiper, 1979). Under these circumstances, "hosts are no longer hosts, just providers of services, while the guests are no longer guests, just customers" (Aramberri, 2001, p. 746). The financial agreement for goods and services replaced "the nonmaterial reciprocity of the old covenant" (Aramberri, 2001, p. 746). This type of commercialized hospitality is based on a 'holy trinity' of provision of food, drink and accommodation. Hospitality can be regarded "as a product, a process, an experience, or all three" (Brotherton, 1999, p. 165). Nevertheless, the purchase of services is much more complex than purchase of manufactured goods and artefacts. Services always include a certain form of social interaction and most frequently partial proximity between consumers and providers: "to buy the service is to buy a particular social or sociological experience" (Urry, 2002, p. 60). However, even hospitality products become an experience: "customers do not buy service delivery, they buy experiences; they do not buy service quality, they buy memories; they do not buy food and drink, they buy meal experiences" (Hemmington, 2007, p. 749). The experience factor of hospitality services relates to their affective value that can transform an instrumental transaction into an emotional transaction (Lugosi, 2008). The emotional work, for instance, contributes to a tourist's good feeling, emerging from displays of helpfulness or friendliness (Urry, 2002). Commercialized interactions in tourism are contrary to the former hospitality covenant. Tourists are exposed to 
fake authenticity and they do not become temporary members of the host environment (Aramberri, 2001). However, experience is more personal category as it refers to human beings - in this case, tourists, their own consciousness and perception. A human being is the experiencing subject, striving for an inner and emic perspective. It will never be possible to record and describe completely another's experiences as "everyone censors or represses, or may not be fully aware of or able to articulate, certain aspects of what has been experienced" (Bruner, 1986, p. 5). The original host-guest polarities have lost their accuracy as they have become confused, when hosts can be migrating workers, or guests can settle in the destination and become hosts. Nevertheless, the conditions of using the host and guest categories have not lost their purposefulness, they are used more reflexively and situationally (Sherlock, 2001; McNaughton, 2006).

\section{Early models of the 'host-guest' relationship in anthropology of tourism}

The effort to define the nature, potential, influence, and impact of interaction between hosts and guests is characterized by the polarity between the negative and the positive approach. The importance of the impacts is also reflected in the fact that "host and guest are not innocent terms" (McNaughton, 2006, p. 647). One of the first concepts of interaction between guests and hosts was presented by Doxey $(1975,1976)$. He defined a fivestage chart - Doxey's irritation model (irridex) in which he reflected on hosts' irritation with the presence of tourists in the destination. The irritation has its source in tourists' physical presence, their number and type, length of their stay, differences and cultural distance between hosts and guests or foreign ownership of local resources - these may be the primary factors that impact on the socio-cultural fabric. This model depends on the host community qualities, number of visitors and growth of the destination. At the same time, this "model suggests that communities pass through a sequence of reactions as the impacts of an evolving tourism industry in their area become more pronounced and their perceptions change with experience" (Faulkner \& Tideswell, 1997, p. 6). Hosts' attitudes are typically positive at the early stage of tourism development in a destination, but they become more and more negative as tourism exerts pressure on the local society.

Doxey's irritation model $(1975,1976)$ presumes a one-direction development when hosts' attitudes express levels of euphoria, apathy, irritation, antagonism, and final level (Fig. 1). Euphoria is typical of the initial enthusiasm linked to tourism development when tourists are welcome. The number of tourists is small and the tourists respect residents and the destination. There is a reciprocal feeling of satisfaction that illustrates a slightly commercial type of interactions. When tourism grows, there is increasing apathy paralleled by a growing number of tourists and their natural acceptance by locals. Hosts see tourists as a source of income, which is why their interactions are more formal and business-like. Hosts start separating their lives from the lives of tourists as their irritation and worries increase. The level of irritation is reached if tourism exceeds the saturation 
point. More and more tourists arrive to a destination that is developed through external investments. Some groups of hosts protest against tourism because of limited availability of natural and cultural resources and tourists' inappropriate behaviour. There is increasing confrontation between local residents and tourists, which results in antagonism. When the number of tourists is too high, they come to be "blamed, fairly or unfairly, for perceived detrimental changes to local lifestyles and society" (Williams, 1998, p. 143). Hosts are openly intolerant of tourists, considering them as exploiters. In the final stage, the destination ceases to be attractive because of the relevant consequences and their destructive impact; tourists move on to different destinations.

Figure 1 Doxey's irritation model with the final level

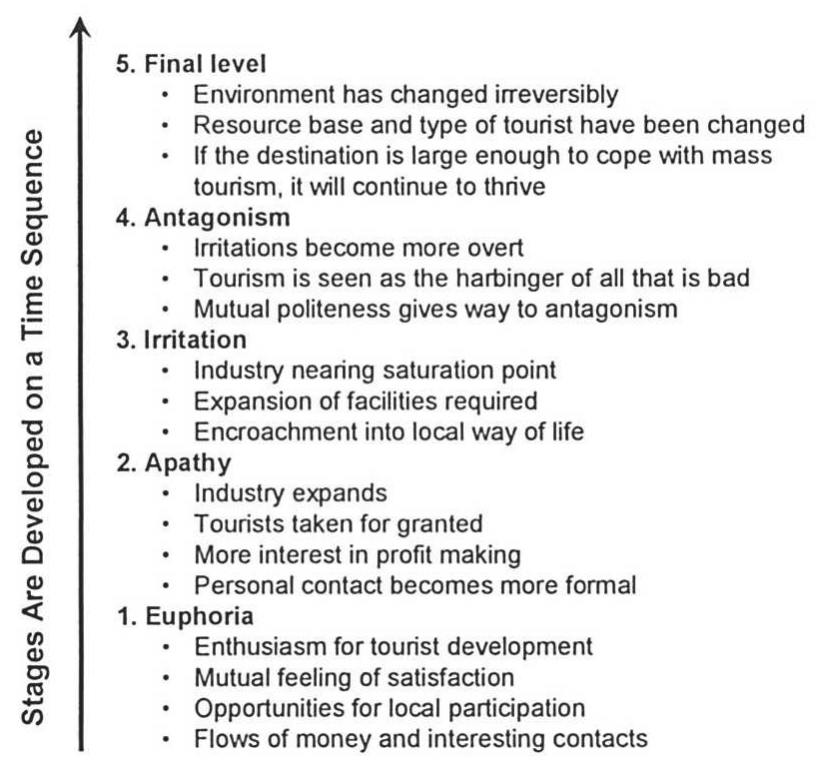

Source: Doxey $(1975,1976)$

Smith $(1977,1989)$ shifted the emphasis from tourists to the critical interest in asymmetric relationships between hosts and guests and the impact of tourism on local residents and environment. Smith institutionalized the terms 'host' and 'guest' in anthropology of tourism and interlinked the degree of socio-cultural impacts with her own tourist typology and the level of tourism in a destination. "The stressful contacts between hosts and guests also appear to increase, proportionate to the larger numbers" (Smith, 1989, p. 14). Antagonism can be found in all tourist areas where tourist density has rapidly grown, and where tourism deepened socio-economic and cultural differences between hosts and guests, intensifying the fight for limited local resources (Smith, 1977). In her further research, Smith points out that modernization and globalization contribute to 
cultural change in tourist destinations. She also mentions the ever smaller distance as communication and transport make the destination look closer, bringing about the problems with time, authenticity, identity, and ethnicity (Smith, 1989). What plays a decisive role is the shift of the nature of tourism from a predominantly private enterprise to a government agencies' business. Tourism is considered to be the solution to economic problems and developmental needs. In addition to globalization of tourism, she admits that the roles of cultural mediators or brokers acting between hosts and guests increase (Smith \& Brent, 2001).

Sutton (1967, p. 220) was among the first to analyse the different nature of mutual interaction between hosts and tourists. He describes interaction as a "series of encounters visitors who are on the move to enjoy themselves $[. .$.$] and hosts who are relatively$ stationary and who have the function of catering to these visitors' needs and wishes." Sutton identified five socio-cultural characteristics of the tourist-host encounter. The first factor, mutual recognition, consists of the guest and host getting to know each other; this relationship has a transitory, non-repetitive, and asymmetric nature. Participants in this relationship are oriented towards achieving immediate satisfaction rather than maintaining a long-term relationship. Because of the transience and unrepeatability of the relationship, they do not take into consideration the future impacts of their current behaviour, which is why there is no sense of need for establishing mutual trust. This is also why the relationships between hosts and guests are partially based on deception and pretended hospitality because both participants may easily escape the consequences of animosity and dishonesty. The second factor includes the fact that a guest and a host share "an orientation to immediate gratification" (Sutton, 1967, p. 221). Guests strive for maximizing experiences, while hosts for maximizing the price for the services they provide. The third factor represents inherent cognitive asymmetry between guests and hosts. This asymmetry in local knowledge manifests when hosts display their advantage and make use of tourists' gullibility. Therefore, interaction "may provide either an opportunity for rewarding and satisfying exchanges or it may stimulate and reinforce impulses to exploitation on the part of the host" (Sutton, 1967, p. 220). Asymmetry is also reflected in the purpose of participants' meetings. While tourism means work for hosts, for tourists it is all about relaxation and leisure; this may increase the power of exploitation of the host with the resultant resentment of guests toward the host. The fourth factor is mutual enrichment when guests savour euphoria from new, non-routine or unusual experiences and hosts gain new experience. The last factor is a problem of relative congruence of values and norms of hosts' and guests' cultures that may in an intercultural situation lead to misunderstandings and conflicts.

\section{Acculturation model of the 'host-guest' relationship in anthropology of tourism}

The acculturation model of contact between hosts and guests has been the core of research with in anthropology of tourism since its inception in the 1960s. Nuñez (1963, p. 352) pointed out "(1) that tourism may bring about rapid and dramatic changes in the 
loci of authority, land-use patterns, value systems, and portions of an economy; (2) that it is a legitimate and necessary area of culture change research; and (3) that the study of tourism may provide another laboratory situation for the testing of acculturation theory." The acculturation process refers to the long-term changes in the host culture as a result of tourist presence. Acculturation relates to "the process wherein members of one culture react to another culture with which they are in contact" (Graburn \& Moore, 1994, p. 237). During the acculturation process, one or several elements of culture are borrowed due to the contact between hosts and guests. This exchange process is not balanced, but rather asymmetric as the dominant guests' culture controls and changes the hosts' culture. The nature of interaction and contact, different levels of socio-cultural integration and socio-economic differences, and other variables often lead to an asymmetric form of cultural borrowing. "Tourists are less likely to borrow from their hosts than their hosts are from them, thus precipitating a chain of change in the host community" (Nuñez, 1989, p. 266). The host community adapts itself as it caters to tourists' needs, attitudes, and values. The interaction and relationships between hosts and guests are characterized by instrumentality, social distance, and stereotyping. The greater the ethnic and cultural distance, the higher the unnatural behaviour and misunderstanding between the two cultures.

In 1970s, new perspectives on the exploitative relationships between developed (foreign metropoles) and developing (dependent destinations) countries came to prominence in the context of acculturation. Turner and Ash pointed out that there were tourist destinations of the developing world that were economically dependent on the North and West. "The tourists' superior economic wealth rapidly erodes the sensuous and aesthetic wealth of cultures that have developed in isolation from the Western world" (Turner \& Ash, 1975, pp. 130-131). The exploitative economic relationships emerge between metropoles and those destinations that become the pleasure-peripheries of the West; a tourist belt surrounding industrial and industrialized areas. "In the past, it was the great commercial centres of the world like Constantinople and Vienna which were threatened. Today, it is the Nomads of Affluence, coming from the new Constantinoples - cities like New York, London, Hamburg or Tokyo - who are creating a newly dependent social and geographic realm: the pleasure periphery" (Turner \& Ash, 1975, p. 11). "Golden hordes", tourists from manufacturing centres using up the natural and cultural potential of a periphery enter tourist destinations. Tourism and relationships between hosts' and guests' cultures emerge as a "form of economic exploitation little different from that of previous decades. If past generations created oil producing, mining, or rubber-growing enclaves, ours has produced tourist resorts" (Turner \& Ash, 1975, p. 249).

The consequences of relationships between metropolitan centers and tourist destinations were elaborated by Nash $(1977,1981,1989)$, who conceptualized tourist areas as a product and project of metropolitan centers. "Such metropolitan centers have varying degrees of control over the nature of tourism and its development, but they exercise it - at least at the beginning of their relationship with tourist areas - in alien regions" (Nash, 1977, p. 35). In such production centers, tourist destinations that serve guests and are in line with their needs are produced and selected. The creation of a tourist desti- 
nation opens interaction between hosts and guests that can be long-term or short-term, cyclical (e.g., seasonal), non-cyclical, simple (the guest-host relationship), or complex (including an elaborate touristic organization). Furthermore, intersocietal transactions between metropolitan centres and tourist destinations are developed there. Conditions of transactions between tourists and hosts are defined not only by dissimilarity, but also by the nature of tourism. "In sum, tourists are separated from their hosts by the facts of strangerhood, the work-leisure distinction, and whatever cultural differences obtain in a particular situation" (Nash, 1989, p. 46). Consequences of tourism in tourist destinations result from the introduction of new socio-cultural reality. Its representatives are a new class of guests characterized by the category of leisure time, expectations and needs that the hosts and their social system adapt to. The resulting interactions are short encounters between hosts and guests that are "artificial, asymmetrical, and unidirectional" (Nash, 1981, p. 468).

The process of cultural dependency in the context of negative impacts of tourism was formulated by Erisman (1983). For locals, tourism is a carrier of economic advantages. "But beyond economics lies the deeper and generally unarticulated fear that the industry's impact is even more pervasive and insidious" (Erisman, 1983, p. 339). Cultural dependency takes place at the level of the relationship between the dominant area, i.e., the centre (guests) and subordinated area, i.e., the periphery (hosts). This subordination and cultural dependency manifests when the residents of the periphery come to perceive their own culture as inferior and dependent on the centre. As a consequence, there is a certain loss of identity as the local economy improves and hosts come to behave, act, and think more and more often like guests. This stabilizes the relationship of dominance and inferiority between the centre and the periphery. Cultural dependency leads to "incorporation of exogenous norms and values into a nation's socialization process" (Erisman, 1983, p. 342). The main motives for cultural development are exogenous elements and influences that erode people's self-esteem (Erisman, 1983). Eventually, local residents lose the desire to maintain their original cultural identity independent of the dominant culture.

The nature of interactions between hosts and guests was defined by de Kadt (1979) through the concepts of place and situation. The encounter between hosts and tourists takes place in a concrete place and situation, 1) where tourists purchase goods or services from hosts (shops and hotels), 2) that hosts and tourists go to or use at the same time (beaches, shops, or bars), 3) where hosts and tourists meet, share their knowledge, and exchange information or ideas. Mutual interactions are conditioned by the type of contact between hosts and guests, the importance of tourism for the community, and the community's tolerance threshold. However, the relationships between hosts and guests are characterized by inequality. Therefore, at the level of the host culture, the demonstration effect is manifested expressing "changes in attitudes, values or behavior which can result from merely observing tourists” (de Kadt, 1979, p. 65). The demonstration effect lies in hosts' imitation of tourists' patterns of behavior. As a consequence of direct contact between hosts and tourists, local residents modify their behavior, attitudes, values, and consumption patterns. Tourists' socio-economic superiority is considered to be 
the desired lifestyle that manifests in hosts' desire to own and consume imported goods and services or in their refusal of traditional values and standards. As a result, there may be a change in the local community's social structure or its economic and political elites may be strengthened.

On the other hand, cultural dependency may manifest itself in the vulnerability of the tourist economy. Tourism is the driving force of economic growth in many island economies that lack other competitive sectors. The global financial crisis revealed the great vulnerability of island territories to external factors. The economy of the Trobriand Islands or Caribbean region is highly dependent on tourism, especially in particular island territories such as the Bahamas, Barbados, or Jamaica. The biggest influences on the reaction of the tourism islands to the global financial crisis were degree of dependence on tourism, dependence on European markets, North American and South American markets or length of time as an independent state or dependent territory (Shareef \& McAleer, 2005). These crisis events result in a decrease in the tourist market, which is associated with a decrease in employment figures in the tourism economy and greater unemployment for the region, as well as a decrease in tourism business revenues. Moreover, crisis events make working and living conditions very stressful for local people. However, crisis events can sometimes provide positive outcomes such as new ideas, new products, or new markets (Okumus \& Karamustafa, 2005).

\section{Construing identity in the 'host-guest' relationship in anthropology of tourism}

Many authors pointed out that the host and tourist relationships turn into commercialized hospitality, they are similar to business transactions and lack spontaneity. Mathieson and Wall (1982) described the relationship between tourists and local residents using the five-stage process. The first feature indicates transience, transitoriness, and superficiality of the relationship. Deeper relationship may only arise at destinations where tourists return to the same accommodation. The second feature is pressure on tourists who go through a wide range of experiences over a short time. Thus, irritation increases if they do not get the experiences they want, or only with delay. The third feature is linked to the isolation of tourists who often separate themselves from the locals and who spend most of their time in a tourist resort and its vicinity with other tourists. Their encounters with local residents are limited to tourist personnel. The fourth feature points out that host and tourist relationships are not spontaneous, but formalized and planned. The fifth feature describes the host-guest relationships as unequal and asymmetric in terms of material wealth and power. In every tourist destination, there are limits to growth that are likely to cause many negative and sometimes even irreversible changes when exceeded, "there is a threshold of tolerance of tourists by hosts which varies both spatially and temporally. As long as the numbers of tourists and their cumulative impacts remain below this critical level, and economic impacts continue to be positive, the presence of tourists in destinations is usually accepted and welcomed by the majority of the host population" (Mathieson \& Wall, 1982, p. 141). 
Van den Berghe (1980, 1994) defined interaction between hosts and guests as a kind of ethnic encounter. It is a form of ethnic relationship that includes three economically unequal groups: tourists, tourees and middlemen. "The touree is the native when he begins to interact with the tourist and modify his behavior accordingly" (van den Berghe \& Keyes, 1984, p. 347). The middlemen manipulate their ethnicity in search of profit and mediate tourist-touree encounters (van den Berghe \& Keyes, 1984). Such encounters transform ethnic members into performers who change their behaviour on the basis of their perception of tourists' expectations. Tourists belong to different cultures, subcultures or ethnic groups, but their common tourist experiences transform them into a 'super-ethnicity' (van den Berghe, 1994, p. 8). The presence of tourists influences the original ethnic groups as it makes their members less original and traditional. Tourism affects real communities and produces pseudo-communities for touristic attention. Not all hosts of an ethnic community are engaged in an ethnicity-for-tourism, but those who are end up forming an additional community, a touristified one. The ethnic identity that is constructed at that stage is also legitimate and authentic to the degree that tourism is also authentic and legitimate in those social spaces (MacCannell, 1992b). Moreover, tourists, with their presence, influence native systems of ethnic relationships and native ethnic hierarchies. One of the impacts of these encounters is the creation and reshaping of hosts' original ethnic identity (van den Berghe, 1980).

According to MacCannell (1984, p. 385), reconstructed ethnicity comes to existence if local residents "begin to use their former colorful ways both as commodities to be bought and sold, and as rhetorical weaponry in their dealings with one another." Reconstructed ethnicity refers to a type of identity that was formed in response to the requirements of Western culture and tourism. The influence of tourism and interactions between hosts and guests may turn local cultures into commodities that include presentation, display, depiction, and preservation of ethnic forms of life. Rituals and special events adapt to tourists' expectations. "The concern here is not with the often bizarre results of the tourists' efforts to 'go native'. Rather, it is with the natives' efforts to satisfy the touristic demand, or to go-native-for-tourists" (MacCannell, 1992, p. 158). Local culture and its elements are preserved as products. As a result, tourists' demand for art, entertainment, and other commodities influence the values and standards of the host cultures. Success of the Western culture in the host culture's transformation defines the degree to which habits and traditions can be quantified, marked, delimited, and traded.

\section{Commodification of culture as a factor of tourism development}

In the 1970s and 1980s, Greenwood $(1977,1989)$ elaborated the concept of commodification that transforms local rituals, celebrations and artifacts into commodities in accordance with tourists' expectations. Commodification of culture refers to a process during which cultural elements are transformed into goods. Commodification can also be seen as a form of cultural adaptation of a particular tourist destination to tourist requirements. A ritual or festivity was originally a symbol of local participants' and 
residents' unity, but under the influence of tourism they lost their cultural meaning and they became a tourist attraction, "commodization of culture in effect robs people of the very meanings by which they organize their lives" (Greenwood, 1977, p. 137). The loss of meaning as a result of commodification leads to erosion of social relationships, loss of authenticity and alienation. Local culture is 'altered and often destroyed' and 'made meaningless' (Greenwood, 1989, p. 173). "The ritual has become a performance for money. The meaning is gone" (Greenwood, 1989, p. 178). The key attributes of local events or artefacts are abstracted and presented in an essentialist form. Commodification changes the value of an original event that is sold for money. In the upshot, traditions, habits, and artefacts "have their price, and if you have the money in hand, it is your right to see whatever you wish" (Greenwood, 1977, p. 136). The consequences include an increasing distribution of wealth and transformation of the stratification system. What occurs is "unprecedented cultural change on people already reeling from the blows of industrialization, urbanization and inflation" (Greenwood, 1977, p. 137).

Shaw and Williams (2004, p. 24) research the commodification process at several levels of the tourist experience and distinguish between goods and services with market value from experience value - "unlike some goods and services, the commodification of tourism is based not only on the labour, capital and natural resources used in production, but also on the 'sign value' or symbolic value of the tourism experience." In the process of commodification of tourist experiences we can distinguish between four possibilities with respect to commodification. First, direct commodification, for example, charging tourists for entrance to beaches, theme parks, museums, local festivities, and performances. Secondly, indirect commodification based on the possibility of buying services that enhance tourists' experiences; these services include, for example, transportation, accommodation, food and selling souvenirs at tourist attractions. Thirdly, part commodification, when tourists arrange food, accommodation, hire a car, or organize a trip themselves. And, fourthly, non-commodification, that occurs when tourists are provided accommodation, food, guide, and other services by their family members or friends. Other examples of non-commodification of tourist experiences can be a stroll in the town, marketplace, taking photographs, hiking, or visiting places where no entrance fees are required. Classification of commodification of tourist experiences is not fixed. In some destinations, there may be different combinations of these four types of commodification and "it is the exact combination of these which, in large part determines place characteristics" (Shaw \& Williams, 2004, p. 26). Elements such as entrance fees, accommodation, food, or sale of souvenirs may represent different types of commodification of tourist experiences than as they are classified. For instance, accommodation in a luxury hotel that is considered, according to the classification, indirect commodification of tourist experiences, may be seen by some tourists as a tourist attraction per se and thus represent rather direct commodification (Shaw \& Williams, 2004).

Cohen (1988) considered the influence that commodification has on the meaning and authenticity of the host culture as positive since performance of events for tourism allows reassessment of their value by the local community. Commodification of the local culture does not result in the destruction of the local culture, quite to the contrary, "the 
emergence of a cultural tourist market frequently facilitates the preservation of a cultural tradition which would otherwise perish. It enables bearers to maintain a meaningful local or ethnic identity which they might have otherwise lost" (Cohen, 1988, p. 382). Emergent authenticity is developed, and it gradually achieves an authentic meaning for the host culture as well as tourists. Therefore, commodification of culture does not necessarily have to suppress the authentic meaning of local culture, traditions, and artifacts. Instead, emergent authenticity contributes to the preservation of culture vitality. "Tourist-oriented products frequently acquire new meanings for the locals, as they become a diacritical mark of their ethnic or cultural identity, a vehicle of self-representation before an external public" (Cohen, 1988, p. 383).

\section{Positive impacts of tourism in the 'host-guest' relationship in anthropology of tourism}

The reversal toward the positive impact of tourism expresses a shift from cultural erosion to cultural involution. Cultural involution relates to the potential and use of tourism for the purpose of revitalizing traditional culture. Tourism can save rituals or events from perishing by providing local residents with new resources or stimuli. The concept of cultural involution was established in anthropology of tourism by McKean (1989, p. 126) who presumed that "tourism introduces new ideas and is a major source of funds. Yet, the tourists expect the perpetuation of ancient traditions, especially in the performing and plastic arts." Cultural involution focuses on the protection of culture through new meanings. This is the reason why, for instance, "locals use holy aspects of cultural performances or artefacts in a new profane context. The profit from interactions between hosts and guests boosted local culture's interest in its own traditions, stimulated artistic creativity and ethnic identity. Local residents are encouraged to value and develop their culture manifestations.

Since the 1990s there has been a growth in the number of studies and concepts that take into consideration positive impacts of tourism on the host culture. Medina (2003) contributed to this discussion claiming that tourism allows for review of hosts' interest and pride in the local culture, cultural heritage, and ethnic identity. That is why hosts focus on manufacture and performance of activities and artifacts. This process includes gaining cultural knowledge in order to satisfy the interest of tourists while hosts refer to texts by anthropologists, ethnographers, and archaeologists. Local cultures "are continually produced and consumed through the actions of archaeologists, tourism promoters, tourists, tours guides, curators, and vendors of artisanal production" (Medina, 2003, p. 357). Tourists also create demand for goods that reflect the local culture and its history. However, tourism in this case does not form new culture. Tourism does not even form commodified culture that would differ from authentic or traditional culture. It is rather a subsequence of hosts' initiative. S/he "utilizes new channels to access traditions that may have persisted across centuries” (Medina, 2003, p. 364). Tourism strengthens the position of culture and identity in local hierarchy while they are underestimated in a different sphere or context. 
Commodification of culture as a tool for boosting ethnic and cultural identity was also elaborated by Cole (2007). Hosts can use tourism to gain local power and external recognition, “tourists' visits per se bring pride and a self-conscious awareness of their traditional culture” (Cole, 2007, p. 955). From hosts' perspective, tourists bring entertainment, economic advantages, and information in the destination. Hosts are proud of their cultural heritage, which is the motivation of tourism. They make use of their traditions and believe that tourism strengthens its importance. "Understood from the perspective of the local people, cultural commodification can be positive" (Cole, 2007, pp. 945-946). Tourism changed hosts' auto-stereotypes, while at the same time it gave the local community and its members faith, a sense of togetherness, integrity and social and political independence. New identity constructed through tourism imprinted the local community with new political and economic capital. Commodification is a way of confirming one's identity, telling one's own story, and getting to know the meaning of local experience and heritage.

\section{Consequences of the 'host-guest' relationship and reactions of the host community}

An encounter between hosts and guests may cause a culture shock, which is a term that was introduced in anthropology of tourism by Furnham (1984). It is a cultural, emotional, and mental reaction of hosts who are exposed to contacts with a foreign culture for a longer period of time. Culture shock is caused by changes, differences, misunderstanding, and a lack of understanding of the foreign culture. "Value differences between native and foreign culture are the most powerful predictors of adaption and shock. The closer one approaches the fundamental values and behaviours that drive them, the easier it is to adapt" (Furnham, 2012, p. 709). Culture shock includes sudden uncertainty, fear, anxiety, disorientation, or confusion in relation to a foreign language, values, standards, habits, rules, and social situation. An individual is not sure of what is expected of him/her and what $\mathrm{s} /$ he can expect from foreign culture and society. Culture shock grows together with longer cultural, social, and economic distance and the length of tourists' stay in the destination (Furnham, 1984). In effect, it is an issue of the lack of social and communication skills that can be minimized through "preparation, orientation, and the acquisition of culturally relevant social skills" (Furnham \& Bochner, 1986, p. 36). Cultural differences may be first linked to curiosity, but once they exceed local community's acceptability, they evoke tension, irritation, aggression, intolerance in the hosts, and may even result in a cultural conflict.

Cultural conflicts were described by Robinson (1999), who claimed that conflicts in tourism occur regularly between various groups. "Representations of tourism as a simplistic and value-neutral exchange in which cultural differences, and 'otherness' are traded for tangible economic gains and elusive social 'well-being' still persist" (Robinson, 1999, p. 26). He defined a total of four contexts in which a cultural conflict occurs: tourism industry-host conflicts, tourist-host conflicts, tourism-tourist conflicts, and host-host 
conflict. "Cultural conflict generally implies some degree of incompatibility between individuals, and between societies and cultures" (Robinson, 1999, p. 6). Conflicts between tourists and host community are influenced by 1) the nature and extent of the commodification of the host culture, 2) use of natural resources and their cultural resources and 3 ) the degree of host community's economic dependence on tourism. What manifests itself at this level is cultural commodification and cultural dependency. The principal type of conflict between tourists and guests is a conflict caused by differences in price. A tourist does leisure activities, whereas a host does his/her work. At the same time, the tourist's presence contributes to the demonstration effect, acceleration of cultural change or, by contrast, it inhibits cultural change due to the protection of local culture. Conflicts between tourism and tourists draw attention to the fact that tourists are not a homogeneous group. "Tourists in any one destination will represent a panoply of cultures. The host community may, or may not, recognize the often subtle differences amongst visiting groups" (Robinson, 1999: 18). Conflicts between hosts and hosts lead to considerations about the differences between different host groups, majority and minority citizens and their impacts on tourism. Conflicts between hosts and hosts are conditioned by historic development of a destination or political or social situation (Fig. 2). Therefore, "tourism is one globalizing influence that can initiate dramatic and irreversible changes within the cultures of host communities" (Robinson, 1999, p. 22).

Figure 2 Dimensions of cultural conflict

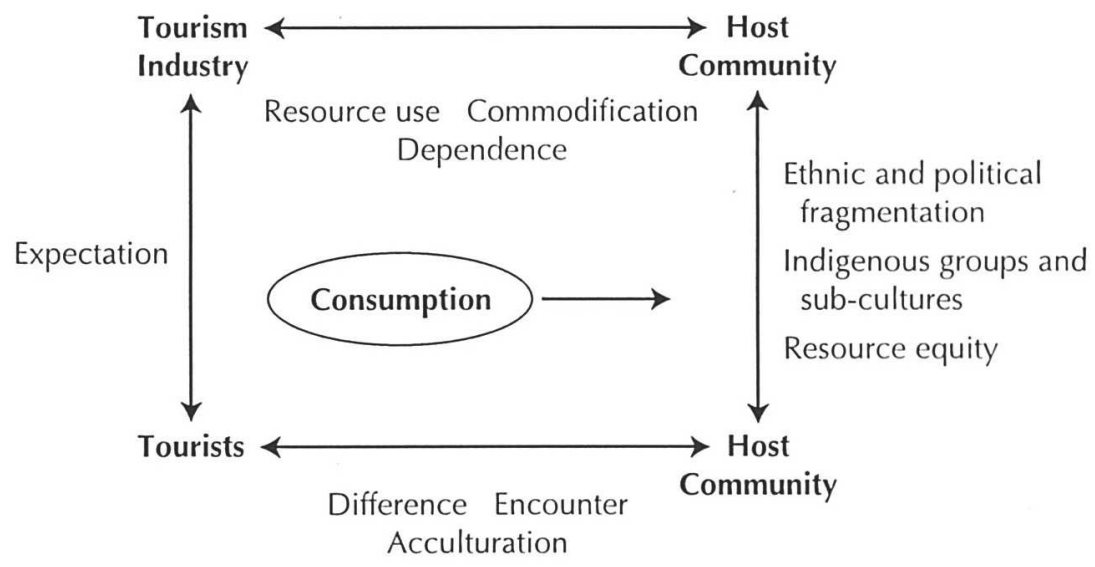

Source: Robinson (1999)

Dogan (1989) elaborated several ideal types of strategies used by the local community in response to tourists' presence and socio-cultural impacts. Local communities may proactively refuse tourism and they make effort to discourage tourists from visiting their destination. This strategy, resistance, is prevalent in areas with long-standing tradition of conflict between local residents and foreigners due to, for instance, colonial rule or 
experience with breach of local standards. Certain communities prefer giving way to tourism and they tolerate tourists' presence, but they avoid direct contact and interaction with them. This type of strategy, retreatism, is opted for in the areas where community members admit to the economic importance of tourism. Giving way to tourism may take a form of general opposition against modernization or it leads to the revitalization and preservation of local tradition. The third type of strategy consists of maintaining the boundaries within which the community actively supports tourism. However, community strictly maintains the boundary between the activities linked to tourism and the activities linked to the local social structure. Boundaries may be maintained by creating special areas for tourists and restricting entrance to private areas. This also applies to distinguishing between cultural aspects that are made for tourists and for local consumption. The fourth strategy emerges if communities use tourism for revitalization of their habits and traditions. Tourism encourages communities to revive traditional handicrafts, art, and rituals, as well as it increases interest in preserving historic buildings. The fifth strategy is adoption when community members replace aspects of their traditional culture with new attitudes and habits represented by tourists. Adoption prevails among younger members of the society and social elites where tourism is seen as a symbol of development and modernization. The five strategies from adoption to presence of tourists are ideal models; in reality, most communities combine several strategies (Dogan, 1989).

Sweet $(1989,1990,1991)$ presented ways and assertive techniques through which local communities can control and regulate interactions with guests. Assertive techniques allow the local community to get over the impacts of contact with guests, strengthen cultural boundaries and exercise a certain degree of power over the dominant group of guests. "As more and more tourists search for contact with real natives, and as the tourist industry continues to nourish these wishes, native people will have to be forthright about the nature of these encounters" (Sweet, 1990, p. 8). Assertive techniques include regulations and secrecy. Regulations form an environment that is unique for tourists who enter a different world where they need to adhere to new obligations and traditional values. Secret is manifested in the protection of traditional religion, in the internal control and power structure and in controlling interactions between hosts and guests. Secret has impact on publishing or excluding information and aspects of culture or rituals. For instance, local community members impose secret on some of these rituals as a means of consolidating cultural integrity against the pressure of curious tourists. Making privileged information accessible results in the loss of power. The result is distinctive restraint providing power and control over strangers, which actually reverses the sphere of dominance. This is because the control of privileged information actually controls a sphere that tourists require, i.e., knowledge of exotic cultures.

Boissevain (1996) drew attention to exaggerating negative socio-cultural impacts of tourism. Approaches to tourism created a false impression according to which local communities did not have social or political resources for efficient coping with sociocultural changes brought about by tourism. In fact, local communities apply one of six strategies. "Host communities take specific, active measures to protect their values and 
customs threatened by outsiders" (Boissevain, 1996, p. 21). The first strategy is covert resistance. Relationships between hosts and tourists are often asymmetric. While tourists are often rich and influential, most employees in tourist industry do not have any economic capital. Forms of covert resistance include rumors and tourist stereotypes that serve hosts who are in the inferior position to maintain their self-esteem. The second strategy of coping with interaction with guests is hiding. "In many societies, communities unenthusiastic about the presence of tourists have now taken to hiding aspects of their culture from visitors" (Boissevain, 1996, p. 16). Hiding may include planning of important rituals and events within the community for a period when tourists are likely not to be there, particularly out of the tourist season. Some cultural aspects are deliberately excluded from tourist consumption, for instance, some kinds of local food. In the areas where important local events and rituals have caught tourists' attention, community members may have the tendency to create new rituals from which tourists are excluded. Additionally, guides can help a community that hides aspects of its culture by excluding certain events or places from their tours. The third strategy is fencing; this may include physical barriers ensuring privacy or moving an activity to a different place. In some cases, tourists are forbidden to enter certain areas. The strategy of fencing informs tourists about the limits of their participation. The fourth strategy is a ritual that represents a form of strengthening hosts' cultural identity. "Rituals protect them from tourism impacts and help them cope with such changes" (Boissevain, 1996, p. 19). The last two strategies consist of organized protest and aggression. The organized protest may be aimed at tourists or tourism mediators. Aggression is a form of violence against guests that arises from community members' opinions of tourists' behavior and attitudes.

\section{Discussion}

Interactions between hosts and guests will continue to provide a useful lens to understand social, political, cultural, economic, and environmental processes as well as characteristic of host and guest. Therefore, a number of theories and models have been developed to describe and measure tourism impacts and ameliorate such impacts. The theories and models evidence that there is a large variety of positions of researchers and a broader range of identifications that accounts for the variety of practices, motivations, and relationships between hosts and guests. Looking at the interactions between hosts leads to viewing them in a different light. They are distinguished with a growth of positive impacts, but ideal types of strategies (Dogan, 1989) and assertive techniques through which local communities can control and regulate interactions with guests (Sweet, 1989, 1990, 1991) can be not only evidence of host power in relation to knowledge, but also a form of protection of host communities' culture, customs, attitudes, or values. In this connection, some theoretical models constituting the beginning of the new development of a conceptual foundation are explored by asking the following questions: to what extent hosts are capable of assessing and perceiving without bias the impacts of tourism; to what extent the knowledge of host regarding tourism and local economy can predict 
their attitudes toward tourism development; and to what extent hosts who were living in the community for a longer period of time affect the tourism development. The reasons why hosts hold certain perceptions towards tourism are still generally unknown.

\section{Conclusion}

What prevailed in anthropologic studies of social interaction between guests and hosts conducted at the turn of the 1960s and 1970s were negative interpretations of the impact that tourism had on host communities and processes of socio-cultural change. These were the consequences of the belief that modern tourism disrupted traditional relationships between hosts and guests based on agreement on protection, reciprocity, and mutual rights and obligations. Relationships between hosts and tourists turned into commercialized hospitality. First anthropological analyses and interpretations of interactions that took place between guests and hosts reflected the increasing irritation of local hosts that was caused by an increased number of tourists in destinations. That was the reason why the level of socio-cultural impacts was linked to a typology of tourists and their number in a given destination. Later on, the research focus shifted away from the studies of tourists to an interest in asymmetric relationships between native hosts and guests and in the analysis of tourism impacts on local residents and their environment. The research results substantiated a hypothesis that different values and standards of hosts' and guests' cultures may lead in an intercultural situation to misunderstandings and conflicts. Another subject of research was the process of acculturation that causes a long-term cultural change in the host culture due to tourists' stay and it deepens the asymmetric relationship between hosts and guests. However, in the last third of the 20th century, a view striving for a deeper understanding of the exploitative relationship that exists between developed (foreign metropoles) and developing (dependent destinations) countries pushes its way forward at the background of studies of acculturation processes in the context of negative impacts of tourism. The problem of cultural dependency is another important research topic; it can be studied at the level or relation between a dominant centre (guests) and inferior periphery (hosts). Cultural conflicts are not omitted either; they occur regularly between culturally different groups.

The concept of negative commodification, which changes culture elements into goods, persisted in anthropology of tourism for a long time. However, since the 1980s, the influence of commodification on the importance and authenticity of the host culture and local identity has begun to be viewed in a positive light. Commodification of culture does not necessarily have to suppress the authentic importance of the host culture, the meaning of local traditions and impressiveness of local artifacts, but quite to the contrary, it can actually boost the vitality of a traditional culture. Therefore, anthropology of tourism saw a research reversal that included a presumption that local communities have social, economic, or political resources allowing them to cope with socio-cultural consequences of tourism. That is the reason why positive impacts of tourism on the host culture began to be researched more intensely in the 1990 s and the presumption that 
tourism enables strengthening of local cultural interests, hosts' pride in their culture, cultural heritage, and ethnic identity have been tested since. Thus, tourism may be also seen as a tool that hosts use in order to gain local power and external recognition as it allows for creation of effective ways of acting and assertive techniques through which representatives of the local host culture may cope positively with interactions with hosts or overcome successfully negative impacts of tourism.

In conclusion, social interaction and relationship between guests and hosts are viewed in anthropologic literature and research with emphasis on negative and positive sociocultural impacts. It is the comparison of impacts and taking effective strategies gradually into considerations that the host community uses in interaction with guests. In this context, tourism starts playing the role of an element in which local communities can control and regulate the degree of power they have over a dominant group of guests. On the other hand, tourism reinforces hosts' cultural identity, makes them reassess their interest in the local culture, cultural heritage, and ethnic identity.

\section{References}

Andrews, H. (2000). Consuming Hospitality on Holiday. In C. Lashley \& A. Morrison (Eds.), In Search of Hospitality: Theoretical Perspectives and Debates (pp. 235-254). Oxford: Butterworth Heinemann.

Aramberri, J. (2001). The Host Should Get Lost: Paradigms in the Tourism Theory. Annals of Tourism Research, 28(3), 738-761. DOI: 10.1016/S0160-7383(00)00075-X.

Boissevain, J. (1996). Introduction. In J. Boissevain (Ed.), Coping with Tourists: European Reactions to Mass Tourism (pp. 1-26). Oxford: Berghahn Books.

Brotherton, B. (1999). Towards a Definitive View of the Nature of Hospitality and Hospitality Management. International Journal of Contemporary Hospitality Management, 11(4), 165-173. DOI: 10.1108/09596119910263568.

Bruner, E. M. (1986). Experience and Its Expressions. In V. W. Turner \& E. M. Bruner (Eds.), The Anthropology of Experience (pp. 3-30). Chicago: University of Illinois Press.

Canziani, B., \& Francioni, J. (2013). Gaze and Self: Host Internalization of the Tourist Gaze. In O. Mouffakir \& Y. Reisinger (Eds.), The Host Gaze in Global Tourism (pp. 19-32). Oxfordshire/ Boston: CABI International.

Chambers, D. (2007). An Agenda for Cutting Edge Research in Tourism. In J. Tribe \& D. Airey (Eds.), Developments in Tourism Research (pp. 233-245). London: Elsevier Science Ltd. DOI: 10.1016/B978-0-08-045328-6.50022-4.

Cohen, E. (1974). Who is a Tourist? A Conceptual Carification. Sociological Review, 22, 527-555. DOI: 10.1111/j.1467-954X.1974.tb00507.x.

Cohen, E. (1988). Authenticity and Commoditization in Tourism. Annals of Tourism Research, 15, 371-386. DOI: 10.1016/0160-7383(88)90028-X.

Cole, S. (2007). Beyond Authenticity and Commodification. Annals of Tourism Research, 34(4), 943-960. DOI: 10.1016/j.annals.2007.05.004.

Crick, M. (1989). Representations of International Tourism in the Social Sciences: Sun, Sex, Sights, Savings, and Servility. Annual Review of Anthropology, 18, 307-344. DOI: 10.1146/annurev.an.18.100189.001515. 
de Kadt, E. (1979). Tourism: Passport to Development? Perspectives on the Social and Cultural Effects of Tourism in Developing Countries. New York: Oxford University Press.

Derrida, J., \& Dufourmantelle, A. (2000). Of Hospitality: Cultural Memory in the Present. Stanford: Stanford University Press.

Dogan, H. Z. (1989). Forms of Adjustment: Socio-Cultural Impacts of Tourism. Annals of Tourism Research, 16, 2165-236. DOI: 10.1016/0160-7383(89)90069-8.

Doxey, G. V. (1975). A Causation Theory of Visitor-Resident Irritants: Methodology and Research inferences. The Sixth Annual Conference Proceedings of the Travel Research Association, San Diego, California, 8-11 September, 195-198.

Doxey, G. V. (1976). When Enough's Enough: The Natives are Restless in Old Niagara. Heritage Canada, 2(2), 26-27.

Erisman, H. M. (1983). Tourism and Cultural Dependency in the West Indies. Annals of Tourism Research, 10(3), 337-361. DOI: 10.1016/0160-7383(83)90061-0.

Faulkner, B., \& Tideswell, C. (1997). A Framework for Monitoring Community Impacts of Tourism. Journal of Sustainable Tourism, 5(1), 3-28. DOI: 10.1080/09669589708667273.

Furnham, A. (1984). Tourism and Culture Shock. Annals of Tourism Research, 11, 41-57. DOI: 10.1016/0160-7383(84)90095-1.

Furnham, A. (2012). The Psychology of Behaviour at Work: The Individual in the Organization. London: Psychology Press.

Furnham, A., \& Bochner, S. (1986). Culture Shock. London: Methuen.

Graburn, N. H. H., \& Moore, R. S. (1994). Anthropological Research on Tourism. In J. R. B. Ritchie \& C. R. Goeldner (Eds.), Travel, Tourism, and Hospitality Research: A Handbook for Managers and Researchers (pp. 233-243). New York: John Wiley.

Greenwood, D. J. (1977). Culture by Pound: An Anthropological Perspective on Tourism as Cultural Commoditization. In V. L. Smith (Ed.), Hosts and Guests: The Anthropology of Tourism (pp. 129-138). Philadelphia: University of Pennsylvania Press.

Greenwood, D. J. (1989). Culture by Pound: An Anthropological Perspective on Tourism as Cultural Commoditization. In V. L. Smith (Ed.), Hosts and Guests: The Anthropology of Tourism (pp. 171-185). Philadelphia: University of Pennsylvania Press.

Griffiths, I., \& Sharpley, R. (2012). Influences of Nationalism on Tourist-Host Relationships. Annals of Tourism Research, 39(4), 2051-2072.

Hemmington, N. (2007). From Service to Experience: Understanding and Defining the Hospitality Business. The Service Industries Journal, 27(6), 747-755. DOI: 10.1080/02642060701453221.

Leiper, N. (1979). The Framework of Tourism: Towards a Definition of Tourism, Tourist, and the Tourist Industry. Annals of Tourism Research, 6(4), 390-407. DOI: 10.1016/0160-7383(79)900033.

Lugosi, P. (2008). Hospitality Spaces, Hospitable Moments: Consumer Encounters and Affective Experiences in Commercial Settings. Journal of Foodservice, 19(2), 139-149. DOI: 10.1111/j.17454506.2008.00092.x.

MacCannell, D. (1976). The Tourist: A New Theory of the Leisure Class. New York: Schocken.

MacCannell, D. (1984). Reconstructed Ethnicity: Tourism and Cultural Identity in Third World Countries. Annals of Tourism Research, 11, 375-391. DOI: 10.1016/0160-7383(84)90028-8.

MacCannell, D. (1992a). Cannibalism Today. In D. MacCannell (Ed.), Empty Meeting Grounds: The Tourist Papers (pp. 17-73). London: Routledge.

MacCannell, D. (1992b). The Locke Case. In D. MacCannell (Ed.), Empty Meeting Grounds: The Tourist Papers (pp. 172-180). London: Routledge. 
Mathieson, A., \& Wall, G. (1982). Tourism: Economic, Physical and Social Impacts. London: Longman.

McKean, P. (1989). Toward a Theoretical Analysis of Tourism: Economic Dualism and Cultural Involution in Bali. In V. L. Smith (Ed.), Hosts and Guests: The Anthropology of Tourism (pp. 119-136). Philadelphia: University of Pennsylvania Press.

McNaughton, D. (2006). The "Host" as Uninvited "Guest": Hospitality, Violence and Tourism. Annals of Tourism Research, 33(3), 645-666. DOI: 10.1016/j.annals.2006.03.015.

Medina, L. K. (2003). Commoditizing Culture: Tourism and Maya Identity. Annals of Tourism Research, 30(2), 353-368. DOI: 10.1016/S0160-7383(02)00099-3.

Molz, J., \& Gibson, S. (2007). Introduction: Mobilizing and Mooring Hospitality. In J. G. Molz \& S. Gibson (Eds.), Mobilizing Hospitality: The Ethics of Social Relations in a Mobile World (pp. 1-26). Aldershot: Ashgate.

Murphy, P. E. (1985). Tourism: A Community Approach. New York, London: Methuen.

Nash, D. (1977). Tourism as a Form of Imperialism. In V. L. Smith (Ed.), Hosts and Guests: The Anthropology of Tourism (pp. 33-47). Philadelphia: University of Pennsylvania Press.

Nash, D. (1981). Tourism as an Anthropological Subject. Current Anthropology, 22(5), 461-481. DOI: $10.1086 / 202722$.

Nash, D. (1989). Tourism as a Form of Imperialism. In V. L. Smith (Ed.), Hosts and Guests: The Anthropology of Tourism (pp. 33-48). Philadelphia: University of Pennsylvania Press.

Nuñez, T. A. (1963). Tourism, Tradition and Acculturation: Weekendismo in Mexican Village. Ethnology, 2, 347-352. DOI: 10.2307/3772866.

Nuñez, T. A. (1989). Touristic Studies in Anthropological Perspective. In V. L. Smith (Ed.), Hosts and Guests: The Anthropology of Tourism (pp. 265-279). Philadelphia: University of Pennsylvania Press.

Okumus, F., \& Karamustafa, K. (2005). Impact of an Economic Crisis: Evidence from Turkey. Annals of Tourism Research, 32(4), 942-961. DOI: 10.1016/j.annals.2005.04.001.

Picken, F. (2006). From Tourist Looking-Glass to Analystical Carousels: Navigating Tourism through Relations and Context. Current Issues in Tourism, 9(2), 158-170.

Robinson, M. (1999). Cultural Conflicts in Tourism: Inevitability and Inequality. In M. Robinson \& P. Boniface (Eds.), Tourism and Cultural Conflicts (pp. 1-32). New York: Cabi Publishing.

Selwyn, T. (Ed.) (1996). The Tourist Image: Myths and Myth Making in Tourism. Chichester: John Wiley \& Sons.

Shareef, R., \& McAleer, M. (2005). Modeling International Tourism Demand and Volatility in Small Island Tourism Economies. International Journal of Tourism Research, 7, 313-333. DOI: $10.1002 /$ jtr.538.

Sharpley, R. (2014). Host Perceptions of Tourism: A Review of the Research. Tourism Management, 42, 37-49. DOI: 10.1016/j.tourman.2013.10.007.

Shaw, G., \& Williams, A. M. (2004). Tourism and Tourism Spaces. London: Sage.

Sherlock, K. (2001). Revisiting the Concept of Hosts and Guests. Tourism Studies, 1, 271-295. DOI: $10.1177 / 146879760100100304$.

Smith, V. L. (Ed.). (1977). Hosts and Guests: The Anthropology of Tourism. Philadelphia: University of Pennsylvania Press.

Smith, V. L. (Ed.). (1989). Hosts and Guests: The Anthropology of Tourism. Philadelphia: University of Pennsylvania Press.

Smith, V. L., \& Brent, M. A. (Eds.). (2001). Hosts and Guests Revisited: Tourism Issues of the 21st Century. New York: Cognizant Communication. 
Sutton, W. A. (1967). Travel and Understanding: Notes on the Social Structure of Touring. International Journal of Comparative Sociology, 8(2), 218-223. DOI: 10.1177/002071526700800206.

Sweet, J. D. (1989). Burlesquing the Other in Pueblo Performance. Annals of Tourism Research, 16, 67-73. DOI: 10.1016/0160-7383(89)90030-3.

Sweet, J. D. (1990). The Portals of Tradition: Tourism in the American Southwest. Cultural Survival Quarterly, 14(2), 2-8.

Sweet, J. D. (1991). 'Let 'em Loose': Pueblo Indian Management of Tourism. American Indian Culture and Research Journal, 15(4), 59-74. DOI: 10.17953/aicr.15.4.409qm26p41220654.

Tucker, H. (2003). The Host-Guest Relationship and Its Implications in Rural Tourism. In D. Hall, L. Roberts, \& M. Mitchell (Eds.), New Directions in Rural Tourism (pp. 80-89). Aldershot: Ashgate Publishing.

Turner L. W., \& Reisinger, Y. (2001). Shopping Satisfaction for Domestic Tourists. Journal of Retailing and Consumer Services, 8, 15-27.

Turner, L., \& Ash, J. (1975). The Golden Hordes: International Tourism and the Pleasure Periphery. London: Constable.

Urry, J. (2002). The Tourist Gaze. London: Sage.

van den Berghe, P. (1980). Tourism as Ethnic Relations: A Case Study of Cuzco, Peru. Ethnic and Racial Studies, 3(4), 375-392. DOI: 10.1080/01419870.1980.9993312.

van den Berghe, P. (1994). The Quest for the Other: Ethnic Tourism in San Cristobel, Mexico. Seattle: University of Washington Press.

van den Berghe, P., \& Keyes, C. F. (1984). Tourism and Re-Created Ethnicity. Annals of Tourism Research, 11, 343-352. DOI: 10.1016/0160-7383(84)90026-4.

Williams, S. (1998). Tourism Geography. London: Routledge. 